\title{
Intelligens szakosodás stratégia minden régiónak? Az elmúlt évek tapasztalatai
}

\author{
Pólónyi-Andor Krisztina \\ Pécsi Tudományegyetem
}

\begin{abstract}
A TANULMÁNY CÉLJA
Az intelligens szakosodás stratégia Európa-szerte meghatározóvá vált a regionális politikában. A 20142020-as tervezési időszak végén, és egyben a következö tervezési periódus előtt állva kifejezetten fontos értékelni a koncepció eredményességét. Sikeres és kevésbé sikeres példák mutatják, hogy az S3 stratégia nem egyformán hatékony minden régióban, ezért felmerül a kérdés, hogy az eredményesség mely regionális tényezőkkel van összefüggésben. A tanulmány célja, hogy bemutassa az S3 koncepció alapjait, legfontosabb gyakorlati tapasztalatait, illetve összefoglalja azokat a változásokat, melyek az elmúlt időszak tanulságai alapján a következő időszak stratégiáját kívánják hatékonyabbá tenni.
\end{abstract}

\begin{abstract}
ALKALMAZOTT MÓDSZERTAN
A tanulmányban alkalmazott módszertan a szakirodalmi feldolgozás. A szakirodalom alapján bemutatásra került az intelligens szakosodás koncepció, a stratégia alkalmazásának tapasztalatai az eltérő fejlettségü régiók tekintetében, a legfontosabb kihívások az S3 alkalmazása során, végül pedig a tapasztalatok alapján továbbfejlesztett koncepció is összefoglalásra került.
\end{abstract}

\section{LEGFONTOSABB EREDMÉNYEK}

A szakirodalom alapján megállapítható, hogy az intelligens szakosodás stratégia a legtöbb uniós régióban bevezetésre került, ám meglehetősen különböző eredményekkel. A fejlett régiók könnyedén teljesítették az S3 feltételeit, míg a lemaradó régiók jellemzően nem rendelkeztek a szükséges kapacitásokkal a stratégia bevezetéséhez. Ennek megfelelően a fejlett régiókban sikeresnek mondható az S3, bár nem minden esetben volt képes jelentős újításokat hozni. A lemaradó régiók inkább csak a stratégia megvalósításához szükséges képességeik fejlesztése által profitáltak a koncepcióból.

\section{GYAKORLATI JAVASLATOK}

Az eltérő fejlettségű régiók különböző eredményeket érhetnek el az S3 segítségével. Ennek megfelelően a regionális stratégia kidolgozása során fontos tisztában lenni azzal, hogy az adott régió melyik fejlettségi kategóriába tartozik, milyen kapacitásokkal rendelkezik, illetve milyen akadályozó tényezőkkel kell szembenéznie, és ennek megfelelően milyen eredményekre számíthat az S3 bevezetése által.

Kulcsszavak: intelligens szakosodás stratégia, regionális politika, S3, regionális fejlődés

Köszönetnyilvánitás: Jelen publikáció az Európai Unió, Magyarország és az Európai Szociális Alap társfinanszírozása által biztosított forrásból az EFOP-3.6.2-16-2017-00017 azonosítójú „Fenntartható, intelligens és befogadó regionális és városi modellek" címủ projekt keretében jött létre.

DOI: 10.15170/MM.2020.54.KSZ.I.07 


\section{BEVEZETÉS INTRODUCTION}

Az intelligens szakosodás stratégia (S3) egy relatíve új fejlesztéspolitikai koncepció, ami rendkívül gyorsan elterjedt az Európai Unión belül. A koncepció alapjait a 'Knowledge for Growth' szakértői csoport (Foray et al. 2011) dolgozta ki, majd később az S3 az EU kohéziós politikájának meghatározó részévé vált. A stratégia különböző elemeit egyes régiók már évtizedek óta alkalmazták (Kroll et al. 2016), továbbá a koncepció több elemet is tartalmaz, mely az innovációs rendszerek, a vállalkozói tevékenység, a növekedés (McCann \& Ortega-Argilés 2015), a regionális gazdaságtan (Lengyel 2018) irodalmából már jól ismert, így az S3 nem tekinthetö teljesen új megközelítésnek. Az Európai Unión belül a legtöbb régió elkészítette a kutatási és innovációs stratégiáját az intelligens szakosodásra (RIS3). Az Európai Bizottság ennek támogatására RIS3 Platformokat szervezett, melyek keretén belül a régiók segítséget kaptak a stratégiájuk kidolgozásához és implementálásához. A gyors elterjedésnek azonban nem csak a koncepció elöremutató jellege adott okot, hanem az is, hogy a 2014-2020-as tervezési periódusban a RIS3 stratégiák elkészítése ex-ante feltételévé vált az EU Strukturális Alapok forrásaihoz való hozzáférésnek (Ortega-Argiles et al. 2013). Számos régió közt Magyarország is elkészítette az intelligens szakosodás stratégiáját (NISzS 2014), melyet Lengyel (2018) vizsgál különös tekintettel az egészségiparhoz kapcsolódó prioritásokra. Magyarország, mint az EU egyik kevésbé fejlett régiója számára különösen fontos kérdés, hogy az S3 képes-e hozzájárulni a lemaradó régiók fejlődéséhez, és ha igen, milyen mértékben, milyen területen várhatók sikerek. A tervezési időszak vége felé közeledve számos tapasztalat gyült össze az intelligens szakosodás stratégia megvalósításával kapcsolatban. Egyértelmúvé vált, hogy az eltérő fejlettségű régiók különböző eredményekre számíthatnak. A gyakorlati tapasztalatok, a sikerek és kihívások segítséget nyújtanak a koncepció továbbfejlesztéséhez (Foray 2019), és tanulságosak lehetnek a következő tervezési időszak stratégiájának kialakítása során.

\section{AZ INTELLIGENS SZAKOSODÁS STRATÉGIA ALAPJAI \\ THE BASIS OF SMART SPECIA- LIZATION STRATEGY}

Foray (2009) alapján az S3 koncepció az Európai Unió kutatási szférájának gyenge hatékonysága miatt jött létre. Az európai kutatási szférát erős fragmentáltság jellemezte, az innovációs politikákat jellemzően nemzeti szinten, egymástól függetlenül, szektorálisan semlegesen hozták létre, továbbá gyakori volt az utánzó magatartás, azaz, hogy a regionális politikákat a helyi környezet, az erösségek és gyengeségek figyelembevétele nélkül, más régiók 'jól bevált' politikáinak másolása révén alakították ki (Foray 2009). Mindez azonban megakadályozta a kritikus tömeg kialakulását, mely a hatékonysághoz szükséges. Sok kicsi, nem túl vonzó rendszer alakult ki, melyek egymással versenyeztek a szükös erőforrásokért, és a pozitív agglomerációs externáliák, a spillover hatások, a méretgazdaságosság előnyei kihasználatlanok maradtak. A koncepció kialakításának további fontos motivációja az EU és az USA közötti termelékenységi rés egyre növekvő mérete, illetve a 2008-as pénzügyi válság gazdasági hatása volt (Foray 2009).

Ahogy a RIS3 útmutatóban Foray és tsai (2012) részletesen bemutatják, az intelligens szakosodás koncepció célja, hogy a politikai támogatásokat és beruházásokat olyan prioritási területekre fókuszálja, melyek illeszkednek a régió sajátosságaihoz, nagy innovációs potenciállal és versenyelőnnyel rendelkeznek, megvan bennük a potenciál a gazdasági szerkezet átalakítására, továbbá egy alulról szerveződő vállalkozói felfedező folyamat (EDP) eredményeképpen kerülnek kiválasztásra. Az S3 stratégia tehát támogatja az innovációt és a kísérletezést, továbbá jól kidolgozott monitoring és értékelő rendszert foglal magában. Az S3 egy területi stratégia, azaz a nemzetközi példák másolása helyett a régió átfogó elemzésén alapul, és figyelembe veszi annak erősségeit, gyengeségeit, az elérhető erőforrásokat, a gazdaság szerkezetét, az innovációs kapacitást és a regionális környezetet (Foray et al. 2012). Rendkívül fontos a stratégiaalkotás megfelelő szintjének meghatározása. Foray és Goenaga (2013) felhívják a figyelmet, hogy amennyiben a stratégia kifejlesztése túl magas területi szinten történik, fennáll a veszélye, hogy az S3 koncepció helyett egyfajta szektorális politika valósul meg. Amennyiben pedig a politika alkotás szintje túl alacsony, felmerül az a veszély, hogy sok mikroszintủ horizontális projekt kerül támogatásra. 
Az S3 továbbá egy alulról szerveződő koncepció, melynek kulcseleme a vállalkozói felfedező folyamat, azaz az EDP. Ennek lényege, hogy a prioritási területek kiválasztása és a stratégia megvalósítása a regionális szereplök széleskörủ bevonásával történjen, mivel ök rendelkeznek az új specializációs területek felfedezéséhez és az innovációs kapacitások felméréséhez szükséges regionális információkkal (Foray et al. 2011). Az EDP folyamat 'vállalkozói' szereplöjének tekinthető minden regionális stakeholder, beleértve az üzleti szféra szereplőit, az egyetemeket, a kutatóintézeteket, a független beruházókat, és a társadalom többi szereplöit. Az S3 koncepció tehát szakít a hagyományos, felülről irányított 'top down' megközelítéssel, melyben a kormányzat a helyi szereplők bevonása nélkül alakítja ki a regionális stratégiát (Foray et al. 2011). Foray (2016) szerint az EDP folyamatnak két fő feladata van. Egyrészt, hogy integrálja a stakeholderek közt megoszló regionális tudást, és felfedezze az innováció és $\mathrm{K}+\mathrm{F}$ azon területeit, melyek hozzájárulnak a regionális versenyképesség növeléséhez, másrészt pedig, hogy olyan információt nyújtson a felfedezett területekröl, mint például annak innovációs potenciálja, regionális beágyazottsága, más területekhez való kapcsolódása, a gazdasági szerkezet átalakításához való hozzájárulási lehetősége.

Foray és tsai (2011) a gazdasági szerkezetátalakulásnak három típusát különböztetik meg. Az 'átalakulás' során az új prioritási fókusz egy teljesen új területen jelenik meg, a 'modernizáció' esetében egy már létező szektor hatékonysága növekszik jelentős mértékben például egy általános célú technológia (GPT) speciális alkalmazása révén, míg a 'diverzifikáció' esetében egy új tevékenység válik vonzóvá egy már meglévő ágazattal való szinergia által. A gazdaság transzformálásához azonban elengedhetetlen a kritikus tömeg megléte. Azaz szükséges, hogy az új lehetőség 'felfedezőjét' elég szereplő kövesse, ezáltal megteremtve azt a gazdasági méretet, azt az új erős ágazatot, mely képes kihasználni az agglomerációban és a méretgazdaságosságban rejlő előnyöket (Foray et al. 2011).

Ahogy Foray (2016) hangsúlyozza, a priorizálási döntések nem tartanak örökké. Az S3 mindig lehetőséget teremt az új területeknek, amik aztán specializációs irányokká válhatnak a régi irányok helyett. Ebböl is következeik, hogy az S3 egy kísérleti politika, azaz nem garantált, hogy minden projekt sikeres lesz. Éppen ezért nagyon fontos nyomon követni a kiválasztott területek fejlődését, megfelelő monitoring és értékelési rendszert kiépíteni, melyek világosan meghatározzák, hogy mik a siker és a kudarc kritériumai (Foray \& Goenaga
2013). Végül az S3 stratégia priorizálási folyamata egy inkluzív folyamat, minden szektornak megadja az esélyt a támogatásra (a korábbi teljesítményétől függetlenül), mely rendelkezik kiváló lehetőségeket nyújtó projekttel.

\section{ELTÉRŐ TAPASZTALATOK A FEJLETT ÉS A FEJLETLEN RÉGIÓKBAN DIFFERENT EXPERIENCES IN DEVELOPED AND LAGGING REGIONS}

Az intelligens szakosodás koncepció 2014-től számos régióban bevezetésre került. Ezt követően hamar felmerült a kérdés, hogy a stratégia vajon tényleg alkalmas-e minden régió számára függetlenül azok fejlettségi szintjétől. Kroll (2015) megvizsgálta a kidolgozott RIS3 stratégiákat, és azok sikeressége alapján három kategóriába sorolta a régiókat. Az úgynevezett 'vezetők' csoportjába az erős kapacitásokkal, és régre nyúló stratégiai tervezési tapasztalattal rendelkező, jellemzően észak- és közép-európai régiók tartoznak. Az 'aktív haszonélvezők' csoportját jellemzően dél-európai régiók alkotják, melyek még elég erős intézményi kapacitásokkal rendelkeznek, ami lehetővé teszi számukra a stratégia megvalósítását. A 'kezdők' csoportjába pedig azok a jellemzően kelet-európai régiók tartoznak, melyekben a hagyományos tervezési kultúra és a centralizált kormányzási gyakorlat komoly kihívássá teszi az S3 bevezetését. Később Trippl és tsai (2019) vizsgálták az intelligens szakosodás megvalósulását, melynek során arra az eredményre jutottak, hogy a terület specifikus tényezőknek köszönhetően valóban jelentős különbségek fedezhetők fel a fejlett, a közepesen fejlett és a fejletlen régiók S3 gyakorlatában.

A fejlett innovációs rendszerrel rendelkező régiók számára az intelligens szakosodás nem hozott sok újitást, számukra gyakran elegendỏ volt a meglévő innovációs politikájukat hozzáigazítani az S3-hoz (McCann \& Ortega-Argilés 2016). A régiók egy része már korábban is alkalmazta a RIS3 néhány kulcselemét, így például Szászország (Baier et al. 2013, Kroll et al. 2016), Felsö-Ausztria (Baier et al. 2013), Baden-Württemberg (Koschatzky et al. 2017), Alsó-Ausztria, Türingia, Franciaország régiói (Kroll et al. 2014), sőt például Bajorország esetében a RIS3 feltételek már eleve adottak voltak az intelligens szakosodás megjelenésekor (Koschatzky et al. 2017). Kétséges tehát, hogy az S3 által a fejlett régiók képesek voltak jelen- 
tős mértékben javítani az innovációs rendszerük minőségén (Kroll 2015). Némi pozitív hatás azért felfedezhető, méghozzá az EDP-hez szükséges kapacitások erősödésében, bár ez nem egyértelmű, hogy gazdasági átalakuláshoz vagy épp a meglévő struktúrák rögzüléséhez vezet (Trippl et al. 2019).

Ezzel szemben a fejletlen régiók számos nehézséggel találták szembe magukat a RIS3 stratégiájuk kidolgozása és megvalósítása során. Ezekre a régiókra jellemző a legnagyobb kihívást jelentő környezet: fejletlen kutatási és innovációs rendszer, az elavult technológiák és a tradicionális szektorok túlsúlya, erős fragmentáltság (Healy 2016), a kritikus tömeg hiánya, gyenge vállalkozói szféra, intézményi heterogenitás és a regionális kormányzat hiánya (Krammer 2017). Capello és Kroll (2016) felhívják a figyelmet, hogy a lemaradó régiók RIS3 stratégiájának sikerességét veszélyezteti az innovációhoz szükséges előfeltételek hiánya, a rögzült sémákból való kitörés képességének hiánya, továbbá a nemzeti vagy nemzetközi prioritás mintázatok másolása a regionális sajátosságok figyelembevétele nélkül. Emellett az is nehézséget jelent számukra, hogy a globális értékláncba jellemzően multinacionális cégek révén kapcsolódnak be, melyek nem érdekeltek a regionális fejlesztésekben. Így a prioritások kiválasztása a helyi KKV szektoron alapul, mely ugyan érdekelt a régió fejlesztésében, de a gazdasági ereje és az abszorpciós képessége elégtelen szintű (Capello \& Kroll 2016). Mindemellett a kelet-európai régiókban hagyományosan 'top-down' típusú tervezési struktúra müködik, melynek keretében komoly kihívást jelent az alulról szerveződő megközelítés alkalmazása (McCann \& Ortega-Argilés 2016). Bár a fejletlen régiók nem képesek teljesen megvalósítani az S3-at, a kormányzati rutinok átalakítása (Hassink \& Gong 2019), az újfajta innovációs gyakorlatok átvétele és a stakeholderek bevonásának új gyakorlata elörelépést jelent számukra (Trippl et al. 2019).

Az eddigi tapasztalatok azt mutatják, hogy az intelligens szakosodás a fejlett (magas egy före eső GDP-vel rendelkező) régiókban müködik a legjobban, míg a kevésbé fejlett, lemaradó régiókban nehézséget jelent az S3-hoz szükséges minimális feltételek megvalósítása is (Hassink \& Gong 2019, Foray 2019). Mindez a regionális innovációs paradoxon jelenlétére utal, miszerint a fejletlen régióknak nagyobb szükségük van az innovációs beruházásokra, mint a fejletteknek, ellenben jóval alacsonyabb az abszorpciós kapacitásuk, mellyel ezeket a forrásokat hasznosítani tudják (Muscio et al. 2015, Hassink \& Gong 2019). Kroll és tsai (2016) felhívják a figyelmet, hogy a stratégia sikeressége nagyban múlik a régiók motivációján is.
Míg például Szászország különösen proaktívnak bizonyult, voltak régiók, melyek motivációja nem biztos, hogy túlmutatott a minimális formális követelmények teljesítésén, és így az ESIF forrásokhoz való hozzáférésen (Kroll et al. 2016, Reimeris 2016).

\section{KIHÍVÁSOK AZ S3 MEGVALÓSÍ- TÁSA SORÁN CHALLENGES DURING IMPLE- MENTION OF S3}

Az S3 koncepció bevezetésekor számos nehézség merült fel. A régiók számára az első kihívást a koncepció lényegének megértése okozta. Gheorghiu és tsai (2016) rávilágítanak, hogy a RIS3 útmutató (Foray et al. 2012) inkább egy elméleti leírás a stratégiaalkotásról, mintsem a gyakorlatban is alkalmazható javaslatok gyüjteménye például az EDP folyamat megszervezéséhez, a prioritások kiválasztásához. Nehézséget jelentett továbbá, hogy a politikaalkotók nem tudták, hogyan támogassák a koncepció megvalósulását (Cooke 2016), illetve a regionális stakeholderek nem értették, hogy mi az S3 és mik az elönyei (Teräs et al. 2015), vagy épp különbözöképpen értelmezték a koncepciót (Reimeris 2016). Hassink és Gong (2019) a specializáció elnevezést kifejezetten összezavarónak találják, mivel szerintük a koncepció sokkal inkább jelent egyfajta intelligens diverzifikációt a potenciális versenyelőny mentén. A specializáció elnevezés föleg az eleve túlszakosodott régiókban okozott bizalmatlanságot (Cooke 2016). Emellett több helyen felmerült a kérdés, hogy az S3 milyen viszonyban áll a korábbi regionális stratégiákkal (Hassink \& Gong 2019), illetve hogyan kapcsolódik a többi EU-s programhoz (Teräs et al. 2015). Például Angliában a korábbi térnélküli stratégiákkal való összeegyeztetés okozott nehézséget (Marlow \& Richardson 2016), Aragon régióban az elöző időszak jól működő programjainak megszünését nehezményezték (Teräs et al. 2015), Litvániában továbbra is a korábbi, kevésbé kapcsolódó program beruházásaira alapoztak (Reimeris 2016), míg Bajorországban továbbra is a klaszterpolitika maradt meghatározó (Koschatzky et al. 2017).

Az S3 stratégiákat eltérő területi szinteken dolgozták ki. Például Baden-Württemberg esetében az alrégiók is lehetőséget kaptak a stratégia elkészítésére (Kroll et al. 2014), Castilla de la Mancha jó példa az autonóm regionális kormányzás szintjén kidolgozott stratégiára, Bucharest-Ilfov és Dél-Kelet-Írország esetében pedig nemzeti szintủ stratégia készült, mely nem különít el regionális fókuszokat 
(Saftescu et al. 2016). Ez utóbbi esetekben kétséges, hogy a RIS3 figyelembe veszi a területi sajátosságokat, mely éppen a stratégia egyik alapelve lenne. Magyarország nemzeti szinten készítette el az S3 stratégiáját, melyben a regionális aspektusok is figyelembe lettek véve. A stratégia megalkotását a Nemzeti Kutatási, Fejlesztési és Innovációs Hivatal koordinálta, továbbá a kidolgozásban jelentős szerepe volt a megyéknek és az EU szakértőivel folytatott konzultációknak is. A regionális szereplők részvételét két körös megyei workshopok, az S3 honlapon elérhető online kérdőív és a stratégia véleményezésére szolgáló felület biztosította. A végső nemzeti konzultáció keretében elfogadott stratégia meghatározta a nemzeti szintű prioritási területeket, melyek minden megyére vonatkoznak, bár eltérő súllyal, továbbá intelligens technológiákat, melyek megyénként eltérőek (NISzS 2014). Marlow és Richardson (2016, 1489) felhívják a figyelmet, hogy a többszintü vezetői struktúrán belül elméleti és gyakorlati szinten is kihívást jelent az S3 alkalmazása, mivel a térnélküli, illetve tág területi dimenzióra fókuszáló hivatalok, mint az EU vagy a nemzeti szint, más értékeket képviselnek, más nézeteket, stratégia alkotási elveket alkalmaznak, mint a regionális szintek. A kormányzat különböző szintjei közötti koordinációs problémák például Silesia (Ortega-Argilés 2012), Nordland (Teräs et al. 2015), és Észak-Kelet-Románia (Healy 2016) esetében merültek fel.

Az S3 koncepció szerint a stratégiákat a területi sajátosságok figyelembevételével, részletes regionális elemzésekre alapozva kell kidolgozni. Ennek ellenére az operatív programoknak csupán $60 \%$-a épült az innovációs környezet részletes SWOT analízisére, csupán 30-40\% részletezi például a KKV-k bevonásának, az erőforrások koncentrációjának módját, továbbá csupán a programok $50 \%$-a tért ki az alkalmazott módszertanra, hívja fel a figyelmet McCann és Ortega-Argilés (2016). Varga és tsai (2020) a gazdasági hatáselemzések hiányára mutatnak rá, melyek éppen a politikai beavatkozások direkt és indirekt hatásait hivatottak becsülni, nem csak az egyes projektek szintjén, hanem a projektek összességét tekintve, így jó eszközként szolgálhatnának az S3 stratégiák tervezési és végső értékelési szakaszában egyaránt. A szerzők a hatásvizsgálatok hiányának okát az S3 politikák elemzése során felmerülő modellezési nehézségekben látják. A kihívások ellenére születtek gazdasági hatáselemző modellek kifejezetten az S3-hoz köthető politikák elemzésére. Ilyen például Sebestyén és Varga (2019) többrégiós ágens alapú modellje, mely az extraregionális kapcsolatokat támogató politikák hatását vizsgálja, Rigby és tsai (2019) modellje, mely a technológiák közti kapcsolódóság és a technológiai komplexitás gazdasági hatásaira koncentrál, továbbá Varga és tsai (2020) földrajzi, makró és regionális modellje, mely a vállalkozást és az interregionális kapcsolatokat támogató politikák gazdasági hatásait elemzi.

A következő kihívást az EDP megvalósítása jelentette sok régió számára. Aragon (Teräs et al. 2015), Litvánia (Reimeris 2016) és Silesia esetében például a regionális szereplők bevonásának, aktivizálásának nehézsége, Scane régió esetében pedig alapvetően a vállalkozói réteg hiánya akadályozta az EDP folyamatot (Ortega-Argilés 2012). A prioritások kiválasztása során további kihívást jelentett az ellentétes érdekekkel rendelkező szektorok közti konszenzus megteremtése például Podlaskie és Lapland régiókban (Teräs et al. 2015). A specializációk kiválasztása során nem csak a regionális adottságok és potenciálok lettek figyelembe véve, hanem jelentős szerepet játszott a lobbi tevékenység (Paliokaite et al. 2016) és a politikai érdekérvényesítés (Reimeris 2016) is. Az S3 koncepciónak megfelelő prioritási területek kiválasztása különös kihívást jelentett azokban a régióban, ahol nincs, vagy nagyon gyenge az innovációs rendszer, alacsony a $\mathrm{K}+\mathrm{F}$ aktivitás, hiányzik a gazdasági tevékenységek kritikus tömege, a képzett munkaerő vagy az egyetemi szféra (Ortega-Argilés 2012, Teräs et al. 2015). Az alulról szerveződő gazdaságfejlesztés megvalósítása Magyarország esetében is nehézségekbe ütközött. Lengyel (2018) problémának látja az érdemi vállalkozói tényfeltárás és a helyi munkaszervezetek hiányát, továbbá a szerző szerint Magyarországon „Nem az alulról-szerveződő, a traded szektorbeli profitorientált vállalkozások terveire épülő, azok innovációs hátterét segítő elképzelések nyertek teret, hanem inkább a szokásos $\mathrm{K}+\mathrm{F}$ gondolatok, föleg egyetemi és kutatóintézeti ötletek." (Lengyel 2018, 31)

A megfelelő értékelési rendszer kidolgozása is hiányosnak bizonyult sok régió esetében. Kleibrink és tsai (2016) kérdőíves felmérése rávilágít, hogy a stratégiák jelentős részében nem voltak megfelelően definiálva az alkalmazandó monitoring folyamatok. Hassink és Gong (2019) felhívják a figyelmet arra, hogy a stratégiák sikerességét mérő módszerek jellemzően kvantitatívak, és nem elegendőek ahhoz, hogy árnyalt képet nyújtsanak a régióban zajló folyamatokról. A szerzők szerint a gazdaságban rejlő potenciál felméréséhez és a stratégia bevezetése utáni átalakulás utókövetéséhez olyan mérési mixet kellene kidolgozni, mely mind kvantitatív, mind kvalitatív módszereket is tartalmaz. 


\section{AZ S3 KONCEPCIÓ VÁLTOZÁSA A TAPASZTALATOK HATÁSÁRA CHANGES IN THE S3 CONCEPT BASED ON THE EXPERIENCES}

Az S3 koncepció bevezetése óta számos tapasztalat, és azokra alapozva kritika is, gyült össze. Foray (2019) megállapítja, hogy a sikeres és kevésbé sikeres példák rávilágítanak az S3 előnyös tulajdonságaira és a nehezen alkalmazható, kevésbé hatékony tényezőire is. Ezáltal lehetőség nyílik a koncepció fejlesztésére, hogy könnyebben alkalmazható legyen a következő időszakban. A szerző hangsúlyozza, hogy az S3 legfontosabb elemei továbbra is érvényesek. Továbbra is meg kell határozni azokat a prioritásokat, melyek a régió erösségein, lehetőségein alapulnak, továbbá fontos, hogy a kiválasztott területek kívánt átalakulási iránya is jól definiált legyen. A vállalkozói felfedező logika ezután is hangsúlyos marad, bár nem tisztán, hanem megfelelő pontokon kombinálva a tervező logikával. Az S3 tehát valahol a felülről lefelé irányuló és az alulról szerveződő logika között helyezkedik el.

Az S3 stratégiák megvalósítására Foray (2019) a korábbi hat lépcsős folyamat helyett egy rugalmasabb, a gyakorlatban könnyebben alkalmazható, csupán három lépcsőből álló iránymutatást ad a régióknak. Ennek első pontja a prioritási területek kiválasztása. Ez egyfajta irányított részvételi folyamat során valósul meg, melyre inkább a tervező logika jellemző. A stratégia régió specifikus része, a differenciálódás és a vállalkozói felfedező logika a következő lépésekben jelenik meg. A második lépés a transzformációs menetrendek kialakítása. A prioritásokat át kell konvertálni konkrét átalakulási tervekké. Meg kell határozni a problémákat és azok megoldását, össze kell gyüjteni a kapcsolódó szereplőket, projekteket, kapacitásokat. A harmadik lépés a cselekvési terv kidolgozása, a transzformációs tevékenység végrehajtása. Ez magában foglalja a pénzügyi eszközök mobilizálását, koordinálását, a projektek pénzügyi értékelését, illetve a monitoring rendszer kidolgozását.

Foray (2019) levonja a tapasztalatokból adódó, és a kutatók által is sokat vitatott tanulságot, miszerint az S3 nem minden régió számára hasznos. A magas egy főre eső GDP-vel rendelkező, erős régiók profitálnak legtöbbet a stratégia bevezetéséből. A nagy regionális gazdaságokban azonban a strukturális változás, a sikeres EDP már nehezebben megvalósítható a regionális szereplök és tevékenységek nagy száma miatt. Emellett egyértelmüvé vált, hogy a lemaradó, strukturálisan gyenge régiók nem rendelkeznek a szükséges kapa- citásokkal az S3 sikeres megvalósításához (Hassink \& Gong 2019, Foray 2019). A probléma megoldását Foray (2019) abban látja, hogy a következő tervezési periódusban a régiók számára választható lesz az S3 alkalmazása, mivel az már nem lesz előfeltétele a pénzügyi forrásokhoz való hozzáférésnek.

\section{ÖSSZEGZÉS SUMMARY}

Az Európai Unió által bevezetett intelligens szakosodás stratégia sikeressége régiónként meglehetősen eltérö. A tapasztalatok azt mutatják, hogy az S3 inkább a fejlett régiók számára előnyös, melyek erős innovációs rendszerrel, fejlett vállalkozói ökoszisztémával, régre nyúló stratégiai tervezési tapasztalatokkal és erős intézményi kapacitásokkal rendelkeznek. Ezzel ellentétben a fejletlen régiók számos kihívással néznek szembe az implementálás során. Az S3 sikerességét nehezítő faktorok összhangban vannak azokkal a tényezőkkel, melyek általában akadályozzák a lemaradó régiók tudásalapú fejlődését (Polónyi-Andor 2020). Ilyen például az elégtelen minőségü intézményi környezet, a gyenge vállalati szféra, a rögzült sémákból való kitörés képességének hiánya és az elégtelen humántőke kapacitás. Ezek feloldására számos javaslat született, melyeket Polónyi-Andor (2020) mutat be. Ezek közül az egyik legfontosabb a régió sajátosságaihoz illő innovációs politika megválasztása, melyre az S3 koncepció is törekszik. A javaslatok között szerepel még az erős vállalkozói ökoszisztéma kialakítása, az intézményi környezet fejlesztése és a tudás abszorpciós kapacitások növelése, melyek mind elengedhetetlenek az S3 megvalósításához. Nem véletlen tehát, hogy a lemaradó régiók, melyekben a tudásalapú fejlődés feltételei hiányoznak, nehézségekkel néznek szembe az S3 koncepció bevezetése során. Ahogy Hassink és Gong (2019), illetve Trippl és tsai (2019) is rávilágítanak, a lemaradó régiókban éppen ezeknek a feltételeknek a kidolgozása, felépítése jelent előrelépést az S3 során. A szükséges tényezők fejlesztése ugyan nem egyszerü feladat, de nem is lehetetlen, amit nemzetközi példák bizonyítanak (Polónyi-Andor 2020). 


\section{HIVATKOZÁSOK REFERENCES}

Baier, E., Kroll, H. and Zenker, A. (2013), “Templates of smart specialisation: Experiences of place-based regional development strategies in Germany and Austria", Working Papers Firms and Region, R5/2013, Karlsruhe

Capello, R. and Kroll, H. (2016), "From theory to practice in smart specialization strategy: emerging limits and possible future trajectories", European Planning Studies, 24(8), 1393-1406, DOI: $10.1080 / 09654313.2016 .1156058$

Cooke, P. (2016), "Four minutes to four years: the advantage of recombinant over specialized innovation - RIS3 versus 'smartspec'", European Planning Studies, 24(8), 1494-1510, DOI : 10.1080/09654313.2016.1151482

Foray, D. (2009), "Understanding "Smart Specialisation"', Pontikakis, D., Kyriakou, D. and van Bavel, R. (eds.), The Question of R\&D Specialisation: Perspectives and policy implications, Luxembourg: EC, Joint Research Centre, 14-26

Foray, D. (2016), "On the policy space of smart specialization strategies", European Planning Studies, 24(8), 1428-1437, DOI: 10.1080/09654313.2016.1176126

Foray, D. (2019), "In Response to 'Six Critical Questions About Smart Spezialisation"', European Planning Studies, 27(10), 2066-2078, DOI:10.1080/09654313.2019.1664037

Foray, D. and Goenaga, X. (2013), "The Goals of Smart Specialisation", EC, Joint Research Centre - Institute for Prospective Technological Studies, Luxembourg, JRC82213

Foray, D., David, P. A. and Hall, B. H. (2011), "Smart specialization, From academic idea to political instrument, the surprising career of a concept and the difficulties involved in its implementation", MTEI working paper, 2011001

Foray, D., Goddard, J., Beldarrain, X. G., Landabaso, M., McCann, P., Morgan, K., Nauwelaers, C. and Ortega-Argilés, R. (2012), Guide to Research and Innovation Strategies for Smart Specialisation (RIS3), Luxembourg: Publications Office of the European Union

Gheorghiu, R., Andreescu, L., and Curaj, A. (2016), "A Foresight Toolkit for Smart Specialization and Entrepreneurial Discovery", Futures, 80, 33-44, DOI:10.1016/j.futures.2016.04.001

Hassink, R. and Gong, H. (2019), "Six critical questions about smart specialization", European Planning Studies, 2710, 2049-2065, DOI:
10.1080/09654313.2019.1650898

Healy, A. (2016), "Smart specialization in a centralized state: strengthening the regional contribution in North East Romania", European Planning Studies, 24(8), 1527-1543, DOI: 10.1080/09654313.2016.1184233

Kleibrink, A., Gianelle, C. and Doussineau, M. (2016), "Monitoring innovation and territorial development in Europe: emergent strategic management", European Planning Studies, 24(8), 1438-1458, DOI: 10.1080/09654313.20 16.1181717

Koschatzky, K., Kroll, H., Schnabl, E. and Stahlecker, T. (2017), "Cluster policy adjustments in the context of smart specialisation? Impressions from Germany", Fornahl, D. and Hassink, R. (eds.), The Life Cycle of Clusters, Cheltenham, UK: Edward Elgar Publishing, 173-200, DOI: $10.4337 / 9781784719289.00018$

Krammer, S. M. S. (2017), "Science, technology, and innovation for economic competitiveness: The role of smart specialization in less-developed countries", Technological Forecasting \& Social Change, 123, 95-107, DOI:10.1016/j. techfore.2017.06.028

Kroll, H. (2015), "Efforts to Implement Smart Specialization in Practice - Leading Unlike Horses to the Water", European Planning Studies, 23(10), 2079-2098, DOI:10.1080/09654313.20 14.1003036

Kroll, H., Böke, I., Schiller, D. and Stahlecker, T. (2016), "Bringing owls to Athens? The transformative potential of RIS3 for innovation policy in Germany's Federal States", European Planning Studies, 24(8), 1459-1477, DOI:10.1080/0 9654313.2016.1159666

Kroll, H., Muller, E., Schnabl, E. and Zenker, A. (2014), "From smart concept to challenging practice: How European regions deal with the Commission's request for novel innovation strategies", Working Paper, Firms and Region, Fraunhofer ISI, R2/2014

Lengyel, I. (2018), „Az intelligens szakosodási stratégiák alapjai, különös tekintettel az egészségiparra", Lengyel, I. (szerk.), Térségek növekedése és fejlődése, Szeged: JATEPress, $11-35$

Marlow, D. and Richardson, K. (2016), "How smart is England's approach to smart specialization? A policy paper", European Planning Studies, 24(8), 1478-1493, DOI: 10.1080/09654313.20 16.1179267

McCann, P. and Ortega-Argilés, R. (2015), "Smart Specialization, Regional Growth and Applications to European Union Cohesion Policy", 
Regional Studies, 49(8), 1291-1302, DOI: 10.1 080/00343404.2013.799769

McCann, P. and Ortega-Argilés, R. (2016), “The early experience of smart specialization implementation in EU cohesion policy", European Planning Studies, 24(8), 1407-1427, DOI: 10.1 080/09654313.2016.1166177

Muscio, A., Reid, A. and Leon, L. R. (2015), “An empirical test of the regional innovation paradox: can smart specialisation overcome the paradox in Central and Eastern Europe?", Journal of Economic Policy Reform, 18(2), 153-171, DOI: $10.1080 / 17487870.2015 .1013545$

NISzS (2014), Nemzeti Intelligens Szakosodási Stratégia, Budapest: Nemzeti Innovációs Hivatal

Ortega-Argilés, R. (2012), "Economic transformation strategies. Smart specialisation case studies", S3 Smart Specialisation Platform

Ortega-Argiles, R., McCann, P., Perianez-Forte, I., Cervantes, M., Larosse, J., and Sanchez, L. (2013), "Innovation-driven Growth in Regions: The Role of Smart Specialisation", OECD SCience, Technology and Industry Policy Papers, 12, Paris: OECD

Paliokaité, A., Martinaitis, Ž. and Sarpong, D. (2016), "Implementing smart specialisation roadmaps in Lithuania: Lost in translation?" Technological Forecasting \& Social Change, 110, 143-152, DOI:10.1016/j.techfore.2016.01.005

Polónyi-Andor, K. (2020), “A tudásalapú fejlődés lehetőségei az EU lemaradó régióiban”, Marketing \& Menedzsment, 54(Különszám1)

Reimeris, R. (2016), "New rules, same game: the case of Lithuanian Smart specialization", European Planning Studies, 24(8), 1561-1583, DOI: 10.1080/09654313.2016.1179722

Rigby, D. L., Roesler, C., Kogler, D., Boschma, R. and Balland, P-A. (2019), "Do EU regions benefit from smart specialization?" Papers in Evolutionary Economic Geography, 1931

Saftescu, R. G., Simion, E., Paul, C. and Mitroi, M. (2016), "Governance of smart specialisation: Experiences of four European regions", Europolity - Continuity and Change in European Governance, 102, 247-264

Sebestyén, T., Varga, A. (2019), “Knowledge networks in regional development: an agent-based model and its application" Regional Studies, 53(9), 1333-1343, DOI: 10.1080/00343404.2019.1622663

Teräs, J., Dubois A., Sorvik, J. O. and Pertoldi M. (2015), "Implementing Smart Specialisation in Sparsely Populated Areas", JRC Technical
Reports, S3 Working Papers Series 10/2015

Trippl, M., Zukauskaite E. and Healy, A. (2019), "Shaping smart specialization: the role of place-specific factors in advanced, intermediate and less-developed European regions", Regional Studies, 1-13, DOI: 10.1080/00343404.2019.1582763

Varga, A., Sebestyén, T., Szabó, N. and Szerb, L. (2020), "Estimating the economic impacts of knowledge network and entrepreneurship development in smart specialization policy", Regional Studies, 54(1), 48-59, DOI: $10.1080 / 00343404.2018 .1527026$ 
Polónyi-Andor Krisztina, tudományos segédmunkatárs andor.krisztina@ktk.pte.hu

Pécsi Tudományegyetem

Közgazdaságtudományi Kar

MTA-PTE Innováció és Gazdasági Növekedés Kutatócsoport Regionális Innováció- és Vállalkozáskutató Központ (RIERC)

\section{Experiences of smart specialization strategy}

\section{THE AIMS OF THE PAPER}

The smart specialization strategy has become an important element of the regional policy inside the European Union. At the end of the budgetary period, 2014-2020, and before the next planning period, it is important to sum up the results of the concept. Successful and less successful examples show, that the efficiency of the S3 strategy is not homogeneous over the regions, therefore the question arises, what can influence the outcome of the strategy. The aim of the paper is to introduce the $\mathrm{S} 3$ concept, its main practical experiences and to sum up the most important changes in the updated concept based on conclusions of previous years.

\section{METHODOLOGY}

The methodology used in the study is literature review. The smart specialization strategy, the experiences of its implementation in the regions with different development level, the most important challenges of S3 are shown based on the literature. In addition, the improved S3 concept is also introduced in the paper.

\section{MOST IMPORTANT RESULTS}

Based on the literature, it can be stated, that the smart specialization strategy has been implemented in the majority of the EU regions with different results. The developed regions could satisfy the conditions of the $\mathrm{S} 3$ easily, but in the lagging regions the realization of the strategy was obstructed typically by insufficient capacities. Accordingly, the S3 can be considered successful in the developed regions, however it could not bring significant improvements in every instance. In case of the underdeveloped regions, the strategy was profitable only by the improvement of capabilities needed for the implementation of the concept.

\section{RECOMMENDATIONS}

The distinct regions can reach different results by S3, thus it is important to know the type of the region, the capacities and the barriers it has to face for strategy making and for determining the expected results.

Keywords: smart specialization strategy, regional policy, S3, regional development

Acknowledgements: This publication/research has been supported by the European Union and Hungary and co-financed by the European Social Fund through the project EFOP-3.6.2-16-2017-00017, titled „Sustainable, intelligent and inclusive regional and city models”. 